\title{
Giresun ve İlçelerinde Yetiştirilen Yerel Erik Çeşitlerinin Pomolojik ve Morfolojik Özeliklerinin Belirlenmesi
}

\section{The Determination of Pomological and Morphological Properties of The Local Plum Types Grown in Giresun and Districts}

\section{Canan ÖNCÜL1}

\section{Ahmet AYGÜN2*}

${ }^{1}$ T.C. Tarım ve Orman Bakanlığ Müdürlüğü, Giresun

iD 0000-0001-9270-7051

${ }^{2}$ Kocaeli Üniversitesi, Fen Edebiyat Fakültesi, Biyoloji Bölümü, 41380, Kocaeli, Türkiye/ Kırgızistan Türkiye Manas Üniversitesi, Ziraat Fakültesi, Bahçe ve Tarla Bitkileri Bölümü, 720044, Bişkek, Kirgizistan.

iD 0000-0001-7745-3380

*Sorumlu Yazar: ahmet.ayguna@kocaeli.edu.tr

Gönderilme Tarihi:

Kabul Tarihi
3 Haziran 2021

25 Haziran 2021

\section{ÖZET}

$\mathrm{Bu}$ araştırma Giresun ili Merkez, Bulancak, Keşap İlçelerinde 2016-2017 yılları arasında yürütülmüştür. Çalışma yapılan alanda 20 farklı isimde anılan yerel erik çeşidi belirlenmiştir. Belirlenen erik çeşitlerinin ağaç özellikleri ve meyve özellikleri tespit edilmiştir. Belirlenen yerel erik çeşitlerinin ortalama meyve ağırlığ 8.02-169.40 g, meyve eni 20.65-42.06 mm, meyve boyu 25.42-42.89 mm, meyve yüksekliği 23.33-43.67 mm, meyve sapı uzunluğu 11.63-17.64 mm, meyve sapı çapı 0.80-2.53 mm, çekirdek ağırlı̆̆ $0.31-1.61 \mathrm{~g}$, titre edilebilir asitlik \%1.15-2.83, pH 2.13-3.83, suda çözünebilir kuru madde miktarının \%7.1218.47 olarak değişim gösterdiği tespit edilmiştir. Erik çeşitlerinde tomurcuk kabarması 25 Ocak-18 Mart tarihleri arasında, tomurcuk patlaması 8 Şubat-23 Mart tarihleri arasında, İlk çiçeklenme 20 Şubat-27 Mart tarihleri arasında, tam çiçeklenme 1 Mart ile 9 Nisan tarihleri arasında, çiçeklenme sonu 10 Mart20 Nisan tarihleri arasında gerçekleşmiştir. Eriklerin hasat tarihleri ise 18 Haziran-31 Ağustos tarihleri arasında 75 günlük bir periyotta dağılım göstermiştir. Yaprak döküm tarihi Ekim ayının 4. haftası ile Aralık ayının 3. haftası arasında olduğu gözlenmiştir. Sonuç olarak, yörede farklı bir çeşit zenginliği tespit edilmiştir.

Anahtar Kelimeler: Genotip, Pomoloji, Prunus spp., SÇKM. 


\section{ABSTRACT}

This research was carried out in Giresun Province, Bulancak, Keşap districts between 2016-2017. In the study area, 20 different varieties of local plums were identified. Tree characteristics and fruit characteristics of plums were determined. The average fruit weight of the determined local plum varieties $8.02-169.40 \mathrm{~g}$, fruit width $20.65-42.06$ $\mathrm{mm}$, fruit length $25.42-42.89 \mathrm{~mm}$, fruit height 23.33 $43.67 \mathrm{~mm}$, stem length $11.63-17.64 \mathrm{~mm}$, stem diameter 0.80-2.53 mm, core weight $0.31-1.61 \mathrm{~g}$, titratable acidity $1.15-2.83 \%$, pH $2.13-3.83$, the amount of water-soluble dry matter was found to vary as $7.12-18.47 \%$. The bud swelling of plum varieties between January 25-March 18, the bud burst between February 8 to March 23, the first nucleation between February 20 to March 27, the full flowering took place between March 1 to April 9, the end of flowering took place between March 10-April 20. The harvest dates of plums ranged from 18 June to 31 August in a period of 75 days. The date of Leaf Casting was observed to be between the 4 th week of October and the 3rd week of December. As a result a, different variety of richness has been identified in the region.

Keywords: Genotype, Pomology, Prunus spp, SSC.

\section{GİRIŞ}

Erik 2000 ylllık kültür tarihine sahip bir meyve türüdür. İtalyan yazar Plinius'un verdiği bilgilerden, çok eski tarihlerde bile çok güzel kültür çeşitlerinin bulunduğu anlaşılmaktadır. Romalılar'ın bu çeşitleri, doğuya yaptıkları seferler sırasında Hazar denizi, Kafkaslar ve Anadolu'dan getirdikleri tahmin edilmektedir (Özbek, 1978). Erik, Rosales takımının Rosaceae familyasından Prunoideae alt familyasının Prunus cinsinden Prunophora alt cinsi içerisinde yer alan sert çekirdekli bir meyve türüdür (ÖzvardarveÖnal, 1990). Erik türleri gen merkezlerinegöre; Avrupa-Asya türleri, Uzak Doğu türleri, Kuzey Amerika türleri olmak üzere 3 grup içerisinde toplanmaktadır (Özçağıran ve ark., 2003). Yabani eriklerin çok eski zamanlardan beri Küçük Asya'dan başlayarak tüm Akdeniz ülkelerini kapsayan geniş alanlarda yetiştiği bilinmektedir. Birçok araştırıcıya göre eriğin orijininin Karadeniz ile Orta
Asya arasındaki bölge olduğu bildirilmektedir (Gavi ve Anderlini, 1978). Davis 1972'de ülkemizde tespit ettiği erik türlerini: Prunus cerasifera Ehrh., Prunus domestica L., Prunus institia L., Prunus spinosa L., Prunus salicina Lindl. ve Prunus simonii Carr. (Mendilcioğlu, 1980) olarak açıklasa da, günümüzde Türkiye'de yetiştirilen erik çeşitleri; $P$. cerasifera (Can erikleri), P. domestica (Avrupa erikleri), $P$. salicina (Japon erikleri) türlerine aittir (Özçă̆ıran ve ark., 2003). Aynı zamanda bu türler ticari bakımından önemlidir (Mendilcioğlu, 1980). Ülkemizde yetiştirilen bu türlerden can eriklerinin tamamı yerli, Avrupa eriklerinin bir kısmı yerli bir kısmı yabancı, Japon eriklerinin ise tamamı yabancı çeşitlerdir (Özçağıran ve ark., 2003). Erik çeşitleri olgunluk zamanlarına göre; erkenci, orta mevsim ve geçci, kullanım şekillerine göre de taze, kurutmalık ve işlenmiş (konserve, reçel vb.) olarak ayrılmaktadır (Tunalıoğlu ve Keskin, 2004). Eriğin bol miktarda B vitaminleri içerdiği, ayrıca potasyum ve magnezyum minerali açısından da zengin bir meyve olduğu kabul edilmektedir. Uzmanlar; karaciğer, kalp ve böbrek hastalıklarına, sindirim rahatsızlığı çekenlere, tuzsuz rejim yapan ve romatizma rahatsızlığı olanlara da erik tüketmelerini önermektedirler (Tunalıoğlu ve Keskin, 2004). Ayrıca yüksek antioksidan kapatiseye sahip besinlerin hücreleri daha iyi koruyabileceği ve daha uzun ve sağlıklı yaşama destek olacağını kanıtlayan veriler mevcuttur. Tufts Üniversitesi uzmanları her gün ortalama 3500 ünite antioksidan tüketimini önermişlerdir. Ortalama bir diyet günde 1000-2500 ünite kadar antioksidan kapasite ihtiva eder. Daha çok antioksidan kapasiteye sahip olmanın en güvenli yolu daha çok sebze ve meyve tüketmektir. Kuru erik (5770 ünite) ve kuru üzüm (2830 ünite) çok güvenilir antioksidan kaynaklarıdır (Müftüoğlu, 2004).100 g taze erik; 66 kalori, $17.8 \mathrm{~g}$ karbonhidrat, $299 \mathrm{mg}$ potasyum, $17 \mathrm{mg}$ fosfor, $2 \mathrm{mg}$ sodyum, $18 \mathrm{mg}$ potasyum, $0.5 \mathrm{mg}$ demir, $0.4 \mathrm{mg}$ lif içermektedir. Ayrıca A, B1, B2, B3, B6, C ve E vitaminlerini içermektedir. Kuru eriğin besin değerinin tazesine göre daha fazla olduğu da belirtilmektedir (Tunalığlu ve Keskin, 2004).

Türkiye'de erik, ilk turfanda meyveler arasında yer alan önemli bir türdür. Erik üretiminde zaman zaman görülen dalgalanma ekolojik koşullardan, özellikle don olaylarından ileri gelmektedir. Türkiye'de erik ağaçları genellikle diğer meyve ağaçları arasında dağınık olarak bulunmaktadır. $\mathrm{Bu}$ tür bahçelerde hastalık ve zararlılarla savaş, gübreleme ve 
budama olması gerektiği gibi yapılmamaktadır. Ancak son yıllarda Ege ve Akdeniz’in kıyı bölgelerinde turfanda yeşil erik yetiştiriciliği önem kazandığından belirtilen sorunlar nedeniyle kapama bahçeler kurulmaya başlanmıştır (Tunalığlu ve Keskin, 2004). Ülkemiz erik yetiştiriciliği ve erik ihracatında dünyada söz sahibi ülkelerden birisidir (Çelikkol 2011). Ülkemizde 2000 yılında erik üretim miktarı 195.000 ton iken, 2020 yılında 329.056 tona ulaşmıştır. Bu üretim 946 tonluk kısmı ise Giresun ilinde gerçekleşmiştir (Anonim, 2020 a).

Daha ekonomik olduğu için Giresun ve ilçelerinde genellikle fındık yetiştiriciliği yapılmakta olup kapama erik bahçelerinin olmadığı, fındık ağaçlarının arasında dağınık halde aile ihtiyacını karşılamak üzere erik yetiştiriciliğinin yapılmış olduğu gözlenmiştir. Nitekim ülkemizdeki toplu meyvelik alanları 2018 yılı itibariyle 206.721 da olup Giresun ve ilçelerinde toplu meyvelik alanı kaydedilmemiştir. Türkiye ortalama erik verimi 36 $\mathrm{kg} / \mathrm{ağaç} \mathrm{iken} \mathrm{araştırmanın} \mathrm{yapıldığı} \mathrm{Giresun'da} \mathrm{erik} \mathrm{verimi}$ $22 \mathrm{~kg} /$ ağaç olduğu görülmektedir. Ayrıca, ağaç başına ortalama verim Merkez İlçede $15 \mathrm{~kg}$, Bulancak İlçesinde $20 \mathrm{~kg}$ ve Keşap İlçesinde $18 \mathrm{~kg}$ olarak kaydedilmiştir. 2018 yılı verilerine göre ülkemizde meyve veren ağaç sayısı 8.301.434 adet iken Giresun'da 42.963 adettir. Toplam erik ağacı sayısı ise ülkemizde 10.158.532 adet iken Giresun'da 47.493 adettir (Anonim, 2019; Anonim 2020b).

Giresun ili erik türlerinin gen merkezi içerisinde yer almasından dolayı geniş bir çeşit ve tür zenginliğine sahiptir. Ancak findık kültürünün bu ilde ve bölgede monokültür şeklini almasından dolayı bu çeşit zenginliği giderek kaybolmaktadır. Bu çalışmanın amacı Giresun ili Merkez, Bulancak ve Keşap ilçelerinde doğal olarak yetiştirilen erik çeşitlerini belirlemek ve bu çeşitlerin fenolojik, morfolojik ve pomolojik özelliklerini ortaya çıkarmaktır.

\section{MATERYAL ve YÖNTEM}

Bu araştırma, 2016 ve 2017 yıllarında Giresun İli Merkez, Bulancak ve Keşap ilçelerinde yürütülmüştür. Araştırmanın bitkisel materyalini, Giresun ilinde doğal olarak yetiştirilen erik genotipleri oluşturmuştur. Çalışma alanında Giresun

İl Tarım ve Orman Müdürlüğü, Bulancak İlçe Tarım ve Orman Müdürlüğü, Ziraat Odaları, Muhtarlar ve üreticilerle görüşülerek yöreye özgü farklı erik çeşitleri tespit edilmiştir. Tespit edilen erik çeşitlerinin ağaçları işaretlenmiş ve hasat döneminde her ağacı temsil edecek meyve örnekleri alınarak laboratuvarda ölçüm ve analizleri yapılmışır.

Araştırma alanında 100 adet erik ağacının 19'u Çakal, 11'i Gügüm, 7'şer adet Can ve Buğday, 6'şar adet Papaz ve Kara Gügüm, 5'şer adet Yumurta, Civil, Kara ve Kemezen, 4’er adet Çıngıl ve Fındık ve 2'şer adet Boğazlı, Elma, Güz, İri Can, Kara Buğday, Orak, Tombul ve Yayla çeşitleri olup her çeşidin ortalaması alınarak değerler elde edilmiştir. Ayrıca bu 100 ağacın 15 tanesinden (1'i Kemezen, 2'si Elma, 1'i Boğazlı, 4’ü Çakal, 3’ü Civil, 4’ü Gügüm) 2 yıl üst üste (2016-2017) örnek alınmışve ortalamaya dahil edilmiştir.

\section{Fenolojik Gözlemler}

Tomurcuk Kabarması : Koyu kahverengi pulların sarıyeşil renge döndüğü, tomurcukların $\% 70$ 'inin kabardığı zaman tomurcuk kabarması tarihi olarak belirlenmiştir.

Tomurcuk Patlaması: Tomurcuklarda beyaz renkli taç yaprakların görülmeye başladığı, tomurcukların içerisinde ilk çiçek ve ilk yaprakların \%70'inin görüldüğü dönem tomurcuk patlaması olarak tespit edilmiştir.

\section{İlk Çiçeklenme: Çiçeklerin \%5’inin açıldığı dönem ilk çiçeklenme tarihi olarak kaydedilmiştir.}

Tam Çiçeklenme: Ağaç üzerindeki çiçeklerin yaklaşık \%75-80'ninin açtığı dönem tam çiçeklenme tarihi olarak belirlenmiştir.

Çiçeklenme Sonu: Taç yaprakların \%75-80'ninin döküldüğü dönem çiçeklenme sonu tarihi olarak kabul edilmiştir.

Hasat Tarihi: Meyvelerin daldan kopma direnci ve meyve rengine göre hasat edildiği tarihtir.

Tam Çiçeklenmeden Hasada Kadar Geçen Gün Sayısı: Tam çiçeklenmeden hasat tarihi arasında geçen 
gün sayısı hesaplanarak bulunmuştur.

Yaprak Dökümü: Erik ağaçlarında yaprakların \%75-80'ninin döküldüğü tarih yaprak dökümü olarak tespit edilmiştir.

\section{Pomolojik Özellikler}

Meyve Ăğrlı̆̆ı (g): Hasat olumundaki 30 adet meyvenin $0.1 \mathrm{~g}$ duyarlıklı hassas terazide tartılıp ortalamalarının alınmasıyla elde edilmiştir.

Meyve Eni (Çap) (mm): Meyvelerin karın çizgisi ile sırt kısmı arasının $0.05 \mathrm{~mm}$ duyarlıklı kumpasla ölçülerek tespit edilmiştir.

Meyve Boyu (mm): Meyvenin sap çukuru ile meyve çiçek ucu arasının uzunluğu 0.05 mm duyarlıklı kumpasla ölçülerek belirlenmiştir.

Meyve Yüiksekliği (mm): Meyve eni yanaklarının arasının mesafesi orta kısmından $0.05 \mathrm{~mm}$ duyarlıkl kumpasla ölçülerek belirlenmiştir.

Meyve Sapı Uzunluğu ve Çapı (mm): Meyve saplarının uzunluğu meyveye bağlandığı ve daldan koptuğu iki uç arasındaki mesafenin $0.05 \mathrm{~mm}$ duyarlıklı kumpasla ölçülmesiyle belirlenmiştir. Sap çapı ise meyve sapının ortasından birbirine dik iki ölçümün ortalamasının alınması ile tespit edilmiştir.

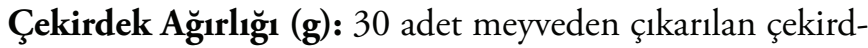
eklerin $0.1 \mathrm{~g}$ duyarlıklı hassas terazide tartılıp ortalamaları alınarak belirlenmiştir.

Meyve Şekil İndeksi: Boyutları belirlenmiş olan meyvelerin şekil indeksi aşağıdaki formül kullanılarak belirlenmiştir.

Şe kil indeks i $=\frac{\operatorname{Meyve~boyu~}(\mathrm{mm})}{[\text { Meyve eni }(\mathrm{mm})+\text { meyve yüksekliği }(\mathrm{mm})] / 2}$

Meyve Suyunun pH'sı: Meyve suyunda pH değeri, dijital pH metre ile belirlenmiştir.
Meyve Rengi: Gözlemsel olarak meyve renkleri 3 kişilik bir grup tarafindan, portakal sarısına yakın sarı renkte, portakal sarısına yakın kırmızımsı renkte, yeşil, kırmızımsı mor, kırmızı, beyazımsı yeşil, menekşe, mor, sarımsı yeşil, yeşilimsi mor, kırmızımsı sarı, sarımsı yeşil olarak belirlenmiş̧ir.

Çekirdeğin Ete Bağlılık Durumları: Çekirdeğin ete bağımlılık durumu, erik meyvesi ortadan ikiye kesilerek 3 kişilik bir grubun gözlemsel olarak bağlı, yarı bağlı ve serbest olarak değerlendirmesiyle kaydedilmiştir.

Et/Çekirdek Oranı : Meyve etinin çekirdeğe oranı, 30 adet meyvenin ve 30 adet meyve çekirdeğinin 0.1 g duyarlıklı terazide değerlerinin belirlenmesinden sonra meyve ağırlığından çekirdek ağırlı̆̆ çıkartılarak etli kısmın ağırlığı bulunmuş ve çıkan sonuç çekirdek ağırlığına oranlanmıştır.

Meyve Tadı: Meyve etinin tadı, çok iyi, iyi, orta, kötü olarak 3 kişilik bir grup tarafindan duyusal olarak belirlenmiștir.

Meyve Aroması: Meyvenin aromasına göre zengin, orta ve az olarak 3 kişilik bir grup tarafından duyusal olarak belirlenmiştir.

Meyve Sululuğu: Meyvenin sululuk durumuna göre sulu, orta, az olarak 3 kişilik bir grup tarafından gözlemsel olarak belirlenmiştir.

Suda Çözünür Kuru Madde Miktarı (\%): Erik meyvelerinin suyu bir tülbent yardımı ile süzülmüştür. Çıkan meyve suyunun suda çözünebilir kuru madde miktarı dijital refraktometre aracılı̆ğ ile ölçülerek \% olarak belirlenmiştir.

Titre Edilebilir Asitlik (\%): Meyve asitliğini belirlemek amaciyla titrasyon yöntemine göre malik asit cinsinden hesaplanmıştır.

Meyve şekli; şekil indeksi 1.25 'den büyük olanlar 'oval', şekil indeksi 1.25 'den küçük olanlar 'yuvarlak' olarak değerlendirilmiştir. 


\section{Morfolojik Özellikler}

Ağacın Taç Yapısı: Ağaçların taç yapıları gözleme dayalı olarak dik, yarı dik ve yayvan olarak belirlenmiştir.

Ağacın Dallanma Durumu: Dal sıklığı dikkate alınarak gözleme dayalı olarak sıkı, orta ve seyrek olarak değerlendirilmiştir.

Ağacın Taç Yüksekliği (m): Dallanmanın başladığı yer ile tepe noktasının yüksekliği gözleme dayalı olarak tespit edilmiştir.

Ağacın Taç Genişliği (m): Yan dalların uç noktaları arasındaki uzaklık (çap) şerit metre ile tespit edilmiştir.

Ağacın Tahmini Yaşı: Üreticinin beyanına göre ve tahmini olarak belirlenmiştir.

\section{ARASTIRMA BULGULARI}

Araşıırma yapılan Giresun'un 3 farklı ilçesinde toplam 100 adet ağaç incelenmiş olup 20 farklı yerel erik çeşidi tespit edilmiştir. Bu çeşitler sırasıyla; Boğazlı, Buğday, Can, Civil, Çakal, Çıngıl, Elma, Fındık, Gügüm, Güz, İri Can, Kara Buğday, Kara Erik, Kara Gügüm, Kemezen, Orak, Papaz, Tombul, Yayla ve Yumurta çeşitleridir.

\section{Fenolojik Gözlemler}

Fenolojik gözlemlerle ilgili bulgulara bakıldığında erik çeșitlerinde, ilk tomurcuk kabarması 25 Ocak tarihinde Can ve İri Can çeşitlerinde görülmüştür. Belirlenen çeşitlerden en son tomurcuk kabarmasının görüldüğü çeşit Tombul çeşidi olup 18 Mart tarihinde gerçekleşmiştir. Çeşitlerin uyanmaları arasında yaklaşık 2 aylık bir periyodun (25 Ocak-23 Mart) olduğu görülmektedir (Çizelge 1). Tomurcuk patlaması ilk olarak 8 Şubat'ta İri Can çeşidinde en son 23 Mart'ta Tombul çeşidinde gözlenmiştir. Giresun ilinde yetiştirilen yerel erik çeşitlerinde ilk çiçeklenmenin çeşitlere göre 20 Şubat ile 27 Mart tarihleri arasında olduğu tespit edilmiştir.

Tam çiçeklenmenin ilk görüldüğü Can ve Kara Buğday çeşitlerinde belirlenen tarih 1 Mart'tır. Tam çiçeklenmenin en son görüldüŭg̈ çeşit Gügüm çeşidi olmuştur ve belirlenen tarih 9 Nisan'dır. Çiçeklenme sonu dönemi bakımından erik çeşitlerinde, 10 Mart-20 Nisan tarihleri arasında bir varyasyon görülmektedir. Çiçeklenme sonunu ilk tamamlayan çeşitler Can ve Kara Buğday çeşitleridir. Çiçeklenme sonunu en son tamamlayan çeşit ise Tombul çeşididir. Bu çeşit aynı zamanda en geç tomurcuk kabarmasının, en geç tomurcuk patlamasının görüldüğü ve en geç ilk çiçeklenen çeşit olarak gözlemlenmiştir Araştırmaya konu olan 20 farklı erik çeşidinden ilk hasata gelen Can çeşididir. Bu çeşit 18 Haziran tarihinde hasat olgunluğuna gelirken diğer çeşitler Temmuz ve Ağustos aylarında hasat olgunluğuna gelmişlerdir. Çeşitler arasında en geç hasat olgunluğuna gelenler ise 31 Ağustos tarihinde Güz ve Kara Gügüm çeşitleridir. Tam çiçeklenmeden hasada kadar geçen gün sayısı erik çeşitlerinde 110-179 gün arasında bir değişim göstermiştir. Doğal olarak en erken hasat olgunluğuna gelen Can çeşidinde bu değer 110 gün iken Kara çeşidinde bu değer 179 gün olarak belirlenmiştir. Erik çeşitleri arasında bu değer bakımından 69 günlük bir fark oluşturmuştur. Yaprak döküm tarihleri bakımından değerlendirildiğinde, Yayla çeşidinin en erken (Ekim ayının 4. Haftası), Tombul çeşidinin ise en geç (Aralık ayının 3. haftası) yapraklarını döktüğü tespit edilmiştir. Diğer çeşitler ise genel olarak Kasım ayında yapraklarını dökmüştür.

\section{Pomolojik Özellikler}

Meyve ağıllıkları bakımından çeşitlerde belirgin farklılıklar olduğu tespit edilmiştir. Nitekim incelenen yerel erik çeşitleri arasında en düşük değere $8.02 \mathrm{~g}$ ile Çıngıl çeşidinde en yüksek değere ise $169.40 \mathrm{~g}$ ile İri Can çeşidinde ulaşılmıştır. Diğer erik çeşitlerinin meyve ağırlıkları bu iki değer arasında dağılım göstermiştir. Meyve ağırlığı bakımından 5 çeşidin meyve ağırlığı 8.02-15.62 g arasında, 10 çeşidin meyve ağırlıkları 15.62-33.41 g arasında, 4 çeşidin 41.23-75.70 $\mathrm{g}$ arasında ve sadece tek bir çeşidin meyve ağırlığının ise $169.40 \mathrm{~g}$ olduğu tespit edilmiştir. Meyve eni ölçümlerinde erik çeşitlerinin meyve eni uzunlukları 20.65-42.06 mm arasında ölçülmüştür. En düşük meyve eni Çıngıl çeşidinde 20.65 mm, en yüksek meyve eni 42.06 mm Güz çeşidinde tespit edilmiştir. Meyve boyu bakımından erik çeşitlerde en düşük değer $25.42 \mathrm{~mm}$ ile Can çeşidinde en yüksek değer ise $42.89 \mathrm{~mm}$ ile Güz çeşidinde belirlenmiştir. Çeşitlerde meyve yüksekliği değerleri $23.33 \mathrm{~mm}$ (Çıngıl) ile 43.67 mm (Güz) arasında ölçülmüştür. Görüldüğü gibi en düşük 
Çizelge 1. Erik Çeşitlerinin Fenolojik Özellikleri

\begin{tabular}{|c|c|c|c|c|c|c|c|c|}
\hline Erik Çeşitleri & T. K* & T. P & İ. Ç & T.Ç & Ç.S. & H.T. & TÇHKGS & YD \\
\hline Boğazlı & 10 Mart & 15 Mart & 22 Mart & 3 Nisan & 15 Nisan & 23 Ağustos & 143 & Aralığın 1. haftası \\
\hline Buğday & 28 Şubat & 4 Mart & 8 Mart & 18 Mart & 28 Mart & 25 Temmuz & 130 & Kasımın 4. haftası \\
\hline Can & 25 Ocak & 10 Şubat & 22 Şubat & 1 Mart & 10 Mart & 18 Haziran & 110 & Kasımın 4. haftası \\
\hline Civil & 19 Şubat & 26 Şubat & 3 Mart & 10 Mart & 25 Mart & $28 \mathrm{Temmuz}$ & 141 & Kasımın 4. haftası \\
\hline Çakal & 18 Şubat & 23 Şubat & 1 Mart & 7 Mart & 17 Mart & 24 Temmuz & 140 & Kasımın 4. haftası \\
\hline Çıngıl & 28 Şubat & 4 Mart & 14 Mart & 24 Mart & 4 Nisan & 29 Ağustos & 159 & Kasımın 4. haftası \\
\hline Elma & 12 Şubat & 23 Şubat & 28 Şubat & 7 Mart & 17 Mart & 24 Temmuz & 140 & Kasımın 3. haftası \\
\hline Findık & 8 Mart & 18 Mart & 26 Mart & 7 Nisan & 17 Nisan & 6 Ağustos & 122 & Aralığın 1. haftası \\
\hline Gügüm & 7 Mart & 17 Mart & 24 Mart & 9 Nisan & 19 Nisan & 13 Ağustos & 126 & Aralığın 1. haftası \\
\hline Güz & 13 Mart & 22 Mart & 27 Mart & 3 Nisan & 13 Nisan & 31 Ağustos & 151 & Kasımın 3. haftası \\
\hline İri Can & 25 Ocak & 8 Şubat & 20 Şubat & 3 Mart & 13 Mart & 6 Temmuz & 126 & Kasımın 4. haftası \\
\hline Kara Buğday & 22 Şubat & 25 Şubat & 27 Şubat & 1 Mart & 10 Mart & 6 Temmuz & 128 & Kasımın 2. haftas \\
\hline Kara & 24 Şubat & 26 Şubat & 28 Şubat & 4 Mart & 21 Mart & 29 Ağustos & 179 & Aralığın 1. haftası \\
\hline Kara Gügüm & 5 Mart & 11 Mart & 18 Mart & 24 Mart & 3 Nisan & 31 Ağustos & 161 & Aralığın 1. haftası \\
\hline Kemezen & 5 Mart & 10 Mart & 15 Mart & 24 Mart & 31 Mart & 8 Ağustos & 138 & Kasımın 2. haftası \\
\hline Orak & 1 Mart & 4 Mart & 9 Mart & 14 Mart & 4 Nisan & $18 \mathrm{Temmuz}$ & 127 & Kasımın 1. haftası \\
\hline Papaz & 15 Şubat & 20 Şubat & 1 Mart & 9 Mart & 28 Mart & 24 Temmuz & 138 & Kasımın 3. haftası \\
\hline Tombul & 18 Mart & 23 Mart & 27 Mart & 7 Nisan & 20 Nisan & 30 Temmuz & 115 & Aralığın 3. haftası \\
\hline Yayla & 18 Şubat & 23 Şubat & 1 Mart & 12 Mart & 24 Mart & $18 \mathrm{Temmuz}$ & 129 & Ekimin 4. haftas 1 \\
\hline Yumurta & 15 Şubat & 20 Şubat & 25 Şubat & 15 Mart & 25 Mart & 18 Temmuz & 126 & Aralığın 1. haftası \\
\hline
\end{tabular}

*TK:Tomurcukların kabarma tarihi, T.P:Tomurcukların patlama tarihi, İ.Ç:İlk çiçeklenme tarihi, T.Ç:Tam çiçeklenme tarihi, Ç.S:Çiçeklenme sonu tarihi, T.Ç.H.K.G.S:Tam çiçeklenmeden hasat tarihine kadar geçen gün sayısı, H.T: Hasat tarihi Y.D:Yaprak dökümü tarihi

değerle en yüksek değer arasında yaklaşık iki katına yakın fark olduğu görülmüştür. Erik çeşitlerinin meyve sapı uzunlukları bakımından da farklılıklar ortaya çıkmıştır (Çizelge 2). Meyve sapı en uzun olan çeşit Gügüm çeşidi olarak belirlenmiştir. Bu çeşitte meyve sap uzunluğu 17.64 mm olarak ölçülmüştür. Meyve sapı en kısa olan çeşit ise meyvenin diğer özelliklerinde de en küçük değerlere sahip olan Çıngıl çeşidinde $(11.63 \mathrm{~mm})$ tespit edilmiştir. Meyve sap çapı bakımından erik çeşitlerinde diğer meyve özelliklerinde olduğu gibi büyük varyasyon belirlenmiştir. Meyve sap çapı $0.80 \mathrm{~mm}$ (Civil) ile $2.53 \mathrm{~mm}$ (Güz) arasında bir değişim gözlenmiştir.

Çıngıl ve Fındık çeşitlerinin meyve şekil indeksleri $1.25^{\prime}$ ten büyük olduğu için oval olarak değerlendirilmiş diğer çeşitler ise bu değerden küçük olduğu için yuvarlak olarak belirlenmiştir. Çeşitlerin farklı meyve kabuğu renklerine sahip çeşiler olduğu tespit edilmiştir. Çeşitlerde çekirdeğin ete bağlılık durumu incelendiğinde 3 çeşitte (Fındık, Güz ve Yayla) çekirdeğin serbest, 3 çeşitte yarı bağlı (Elma, Gügüm ve Tombul) diğer 14 çeşidin çekirdeğinin ete bağlı olduğu gözlemlenmiştir. Et /çekirdek oranı en düşük değer 17.42 ile Yayla çeşidinde en yüksek değer 175.45 ile İri Can çeşidinde tespit edilmiştir. Yörede yetiştirilen erik çeşitlerinde meyve tadı, aroması ve meyve sululuk durumları bakımından geniş bir varyasyonun olduğu tespit edilmiştir (Çizelge 3).

Çeşitlere ait meyvelerin SÇKM değerlerinin \%7.12 ile $\% 18.47$ arasında, titre edilebilir asitlik oranlarının \%1.15 
Çizelge 2. Erik Çeşitlerinin Pomolojik Özellikleri

\begin{tabular}{|l|c|c|c|c|c|c|c|}
\hline \multicolumn{1}{|c|}{ Erik Çeşitleri } & $\mathrm{MA}(\mathrm{g})$ & $\mathrm{ME}(\mathrm{mm})$ & $\mathrm{MB}(\mathrm{mm})$ & $\mathrm{MY}(\mathrm{mm})$ & $\mathrm{SU}(\mathrm{mm})$ & SÇ $(\mathrm{mm})$ & ÇA $(\mathrm{g})$ \\
\hline Boğazlı & 25.10 & 32.65 & 38.38 & 33.77 & 15.51 & 1.63 & 0.87 \\
\hline Buğday & 26.76 & 32.35 & 36.70 & 34.42 & 14.74 & 1.57 & 0.99 \\
\hline Can & 41.23 & 26.04 & 25.42 & 26.97 & 14.47 & 0.90 & 1.61 \\
\hline Civil & 11.59 & 25.60 & 27.40 & 26.69 & 14.29 & 0.80 & 0.60 \\
\hline Çakal & 25.10 & 28.18 & 27.97 & 29.17 & 13.51 & 0.96 & 0.98 \\
\hline Çıngıl & 8.02 & 20.65 & 26.11 & 23.33 & 11.63 & 1.32 & 0.31 \\
\hline Elma & 33.41 & 37.87 & 37.91 & 37.92 & 13.03 & 1.16 & 0.96 \\
\hline Fındık & 10.03 & 24.06 & 28.43 & 24.77 & 14.19 & 1.30 & 0.39 \\
\hline Gügüm & 28.05 & 34.18 & 38.70 & 36.10 & 17.64 & 1.70 & 1.05 \\
\hline Güz & 50.23 & 42.06 & 42.89 & 43.67 & 12.02 & 2.53 & 1.32 \\
\hline İri Can & 169.40 & 36.61 & 35.80 & 37.91 & 13.99 & 1.28 & 0.96 \\
\hline Kara Buğday & 75.70 & 32.46 & 33.12 & 35.40 & 13.56 & 1.85 & 0.85 \\
\hline Kara & 15.62 & 28.20 & 27.94 & 29.25 & 12.93 & 1.12 & 0.72 \\
\hline Kara Gügüm & 28.24 & 33.43 & 39.41 & 36.23 & 14.94 & 1.62 & 0.99 \\
\hline Kemezen & 13.64 & 26.10 & 33.44 & 26.96 & 16.57 & 1.50 & 0.56 \\
\hline Orak & 25.62 & 32.05 & 36.56 & 34.25 & 17.61 & 1.17 & 0.91 \\
\hline Papaz & 56.60 & 31.19 & 29.19 & 31.99 & 13.55 & 1.08 & 0.74 \\
\hline Tombul & 22.85 & 31.27 & 34.30 & 33.68 & 13.3 & 2.23 & 0.71 \\
\hline Yayla & 12.90 & 26.94 & 28.25 & 27.87 & 17.18 & 0.83 & 0.70 \\
\hline Yumurta & 28.18 & 34.32 & 35.45 & 36.09 & 15.09 & 2.09 & 0.93 \\
\hline
\end{tabular}

MA: Meyve Ağırlı̆̆ı; ME: Meyve Eni, MB: Meyve Boyu; MY: Meyve Yüklsekliği; SU: Sap uzunluğu; SÇ: Sap çapı; ÇA: Çekirdek Ağırlı̆̆ı

Çizelge 3. Erik Çeşitlerinin Bazı Meyve ve Çekirdek Özellikleri

\begin{tabular}{|c|c|c|c|c|c|c|c|}
\hline & \multicolumn{7}{|c|}{ Meyve Özellikleri } \\
\hline Erik Çeşitleri & Şekil İndeksi & Meyve Rengi & $\begin{array}{l}\text { Çekirdeğin ete } \\
\text { bağlılık durumu }\end{array}$ & $\begin{array}{l}\text { Et/çekirdek } \\
\text { oranı }\end{array}$ & Tad & Aroma & Sululuk \\
\hline Boğazlı & Yuvarlak & $\begin{array}{l}\text { Portakal sarısına yakın sarı } \\
\text { renkte }\end{array}$ & Bağl1 & 27.85 & Çok İyi & Zengin & Orta \\
\hline Buğday & Yuvarlak & $\begin{array}{l}\text { Portakal sarısina yakın } \\
\text { kırmızımsı renkte }\end{array}$ & Bağl1 & 26.03 & Çok İyi & Zengin & Orta \\
\hline Can & Yuvarlak & Yeşil & Bağl1 & 24.60 & Orta & Orta & Orta \\
\hline Civil & Yuvarlak & Kırmızımsı mor & Bağl1 & 18.31 & Orta & Orta & Orta \\
\hline Çakal & Yuvarlak & Kırmızı & Bağl1 & 24.61 & Orta & Orta & Orta \\
\hline Çıngıl & Oval & Beyazımsı yeşil & Bağl1 & 24.87 & Çok İyi & Zengin & Orta \\
\hline Elma & Yuvarlak & Menekşe & Yarı Bağlı & 33.80 & Orta & $\mathrm{Az}$ & Orta \\
\hline Findık & Oval & Mor & Serbest & 24.71 & İyi & Orta & Orta \\
\hline Gügüm & Yuvarlak & Sarımsı yeşil & Yarı Bağlı & 25.71 & İyi & Orta & Orta \\
\hline Güz & Yuvarlak & Yeşilimsi mor & Serbest & 37.05 & Orta & Orta & $\mathrm{Az}$ \\
\hline İri Can & Yuvarlak & Kırmızımsı sarı & Bağlı & 175.45 & Çok İyi & Zengin & Sulu \\
\hline Kara Buğday & Yuvarlak & Mor & Bağglı & 88.05 & Çok İyi & Zengin & Orta \\
\hline Kara & Yuvarlak & Mor & Bağgli & 20.69 & Orta & Orta & Orta \\
\hline Kara Gügüm & Yuvarlak & Mor & Bağgli & 27.52 & Çok İyi & Zengin & Orta \\
\hline Kemezen & Yuvarlak & Mor & Bağgli & 23.35 & Çok İyi & Zengin & Orta \\
\hline Orak & Yuvarlak & Mor & Bağgli & 27.15 & Çok İyi & Zengin & Sulu \\
\hline Papaz & Yuvarlak & Kırmızımsı sarı & Bağl1 & 75.48 & İyi & Orta & Orta \\
\hline Tombul & Yuvarlak & Yeşil & Yarı Bağlı & 31.18 & Orta & Orta & Orta \\
\hline Yayla & Yuvarlak & Menekşe & Serbest & 17.42 & Kötü & $\mathrm{Az}$ & $\mathrm{Az}$ \\
\hline Yumurta & Yuvarlak & Sarımsı yeşil & Bağl1 & 29.30 & Çok İyi & Zengin & Sulu \\
\hline
\end{tabular}


Çizelge 4. Erik Çeşitlerinin Bazı Kimyasal Özellikleri

\begin{tabular}{|c|c|c|c|}
\hline Erik Çeşitleri & SÇKM (\%) & TEA $(\%)$ & $\mathrm{pH}$ \\
\hline Boğazlı & 17.23 & 1.42 & 3.63 \\
\hline Buğday & 13.91 & 1.57 & 3.50 \\
\hline Can & 7.12 & 2.20 & 3.25 \\
\hline Civil & 10.60 & 2.43 & 3.04 \\
\hline Çakal & 11.31 & 2.13 & 2.13 \\
\hline Çıngıl & 17.98 & 1.22 & 3.83 \\
\hline Elma & 9.67 & 2.83 & 2.97 \\
\hline Findık & 14.48 & 1.17 & 3.68 \\
\hline Gügüm & 16.52 & 1.37 & 3.47 \\
\hline Güz & 17.55 & 1.70 & 3.58 \\
\hline İri Can & 11.95 & 2.30 & 3.39 \\
\hline Kara Buğday & 11.85 & 1.42 & 3.51 \\
\hline Kara & 12.12 & 2.36 & 3.35 \\
\hline Kara Gügüm & 16.10 & 1.18 & 3.64 \\
\hline Kemezen & 18.47 & 1.22 & 3.72 \\
\hline Orak & 12.30 & 1.15 & 3.67 \\
\hline Papaz & 9.41 & 2.48 & 3.22 \\
\hline Tombul & 13.60 & 1.58 & 3.58 \\
\hline Yayla & 11.35 & 1.97 & 3.51 \\
\hline Yumurta & 11.56 & 1.56 & 3.46 \\
\hline
\end{tabular}

ile \%2.83 arasında ve meyve suyu $\mathrm{pH}$ değerlerinin 2.13 ile 3.82 arasında değişim gösterdiği saptanmıştır.

\section{Morfolojik Özellikler}

Yörede yetiştirilen yerel erik çeşitlerinin ağaç özellikleri incelendiğinde Civil, Fındık, Kara Gügüm, Kemezen, Orak ve Papaz çeşitlerine ait ağaçların yarı dik, diğer çeşitlerin dik yapılı oldukları belirlenmiştir. Ağaçların dallanma durumları bakımından ise Çıngıl çeşidinin seyrek, Boğazlı, Buğday, Kara Buğday, Kemezen, Orak ve Yumurta çeşitlerinin orta ve diğer çeşitlerin ise sıkı dallanma gösterdiği görülmüştür. Ağaçlarda taç yüksekliği değerleri 2 $\mathrm{m}$ ile $14 \mathrm{~m}$, taç genişlikleri ise 2 ile $8 \mathrm{~m}$ arasında değişim göstermektedir. Ağaçların ortalama tahmini yaşları 5 ila 40 yıl arasında değişmektedir (Çizelge 5).
Çizelge 5 .Erik Çeşitlerinin Ağaç Özellikleri

\begin{tabular}{|c|c|c|c|c|c|}
\hline $\begin{array}{l}\text { Erik } \\
\text { Çeşitleri }\end{array}$ & $\begin{array}{l}\text { Ağacın } \\
\text { taç } \\
\text { yapıs1 }\end{array}$ & $\begin{array}{c}\text { Ağacın } \\
\text { dallanma } \\
\text { durumu }\end{array}$ & $\begin{array}{l}\text { Taç } \\
\text { Yüksekliği } \\
\text { (m) }\end{array}$ & $\begin{array}{l}\text { Ağacın } \\
\text { genişliği } \\
(\mathrm{m})\end{array}$ & $\begin{array}{c}\text { Ağacın } \\
\text { ortalama } \\
\text { yaş1 (yıl) }\end{array}$ \\
\hline Boğazlı & Dik & Orta & 10 & 6 & 35 \\
\hline Buğday & Dik & Orta & 3 & 2 & 40 \\
\hline Can & Dik & Sik1 & 10 & 6 & 40 \\
\hline Civil & Yarı Dik & Sik1 & 5 & 3.5 & 5 \\
\hline Çakal & Dik & Sik1 & 5 & 4.7 & 6 \\
\hline Çııngıl & Dik & Seyrek & 2 & 2 & 9 \\
\hline Elma & Dik & Sik1 & 6.5 & 7 & 10 \\
\hline Findık & Yarı Dik & S1k1 & 7 & 7 & 15 \\
\hline Gügüm & Dik & Sik1 & 8 & 7 & 25 \\
\hline Güz & Dik & Sik1 & 6 & 6 & 8 \\
\hline İri Can & Dik & Sik1 & 14 & 6 & 15 \\
\hline $\begin{array}{l}\text { Kara } \\
\text { Buğday }\end{array}$ & Dik & Orta & 5 & 6 & 25 \\
\hline Kara Erik & Dik & Sik1 & 4.5 & 4.5 & 16 \\
\hline $\begin{array}{l}\text { Kara } \\
\text { Gügüm }\end{array}$ & Yarı Dik & Sik1 & 11 & 5 & 9 \\
\hline Kemezen & Yarı Dik & Orta & 12 & 6.5 & 12 \\
\hline Orak & Yarı Dik & Orta & 10 & 8 & 20 \\
\hline Papaz & Yarı Dik & Sik1 & 8 & 6.5 & 10 \\
\hline Tombul & Dik & Sik1 & 12 & 4.5 & 32 \\
\hline Yayla & Dik & Sik1 & 7 & 6 & 10 \\
\hline Yumurta & Dik & Orta & 6 & 3.8 & 8 \\
\hline
\end{tabular}

\section{TARTIŞMA ve SONUÇ}

Araştırmamızda tomurcuk kabarması çeşitler arasında farklı tarihlerde gerçekleşmiştir. Bu tarihler 25 Ocak-18 Mart tarihleri arasındadır. Bu bulgular, Beyhan (2005)'nın Darende'deki (7-22 Nisan) araştırmasından çok daha önce olduğu belirlenmiştir. Bu tarih bölgede yetişen diğer ılıman iklim meyveleri için dinlenme dönemidir. Ancak yaprağını döken 1lıman iklim meyveleri içerisinde bademden sonra ilk çiçeklenen bazı bölgelerde bademle birlikte çiçeklenen tür eriktir. Eriğin bu özelliği araştırmamızda da kendini göstermiştir. Nitekim Özkarakaş ve ark. (2006)'nın Menemen'deki çalışmasında bir bölgede erik yetiştirilip yetiştirilemeyeceğini etkileyen en önemli faktörün sıcaklık 


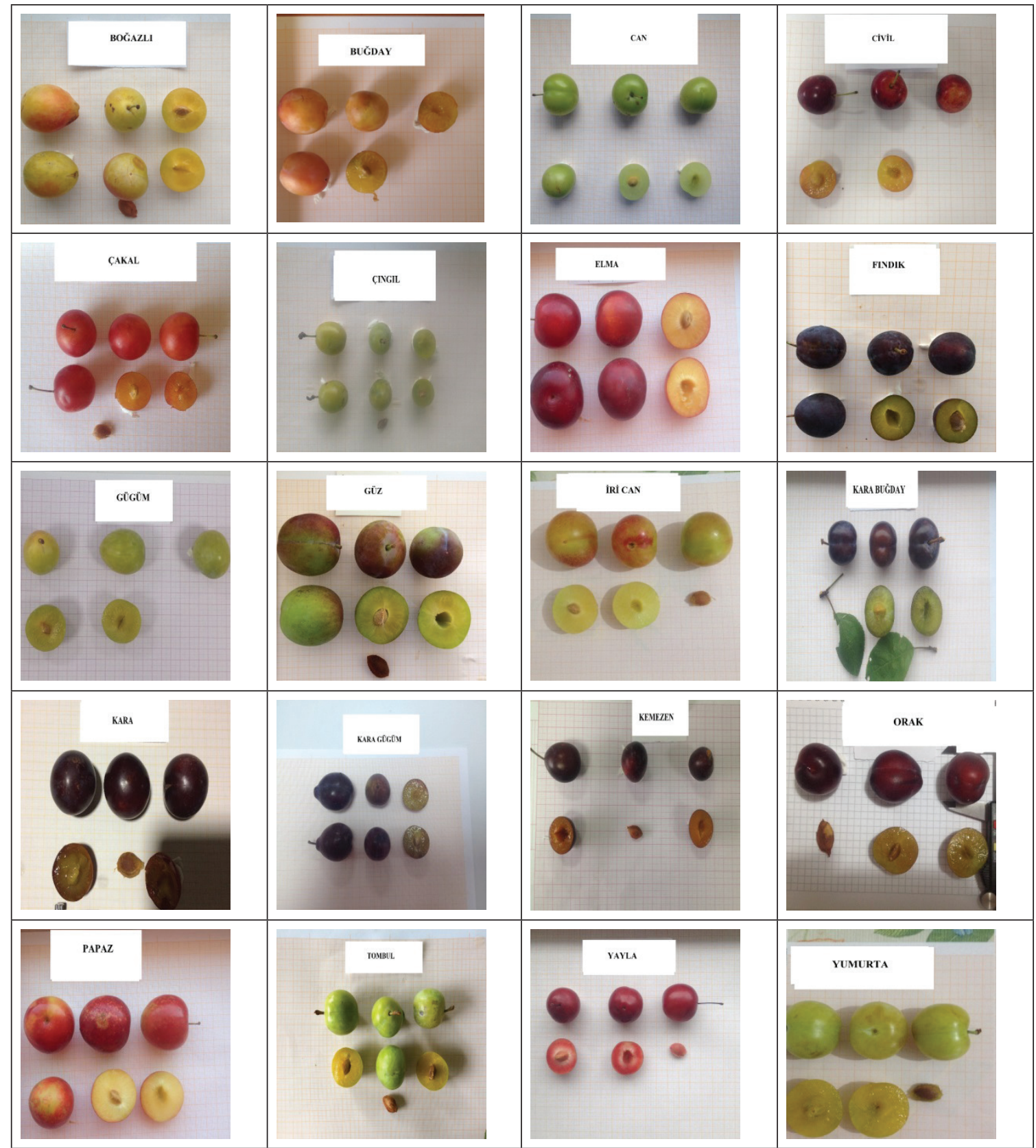

Şekil 1. Erik Çeşitlerine Ait Meyve Görünümleri

olduğu erik ağaçlarının bademden sonra en erken çiçek açan ağaçlar olduğu bu nedenle sıcaklık ve diğer iklim koşullarından en çok etkilenen ağaçların erik ağaçları olduğu özellikle de yeşil erikler olduğu belirtilmiştir. Bu sebeple de eriklerin fenolojilerinin bilinmesinin önemli olduğu vurgulamıştır. Bu çalışmada yerel erik çeşitlerinde tomurcuk patlaması 8 Şubat-23 Mart tarihleri arasında gerçekleşmiştir (Çizelge 1). Bu sonuçlar, Beyhan (2005) (10-24 Nisan) ve Kuba (2015) tarafindan elde edilen sonuçlara göre (5-27 Nisan) oldukça erken, Yaşar (2019)'ın Iğdır'da yapılan (7-18 Mart) araştırması ile de kısmen uyumlu kısmen farklılıklar göstermiştir. Bu farklılıkların ekolojik faktörlerden yada tamamen genotipten kaynaklanabileceği düşünülmektedir. Araştırma yöresinde incelemeye alınan erik çeşitlerinde yapılan gözlemlerde çeşitlerin ilk çiçeklenme tarihleri 20 Şubat-27 Mart arasında belirlenmiştir. Bu sonuçlar, Yaşar (2019)'ın Iğdır'daki (14-23 Mart) araştırmalarından kısmen erken ve Kuba (2015)'nın Erciş (Van) yöresindeki (24 Nisan-15 Mayıs) araştırmalarından daha erken tarihte, Özkarakaş ve ark. (2006)'nın Menemen'deki (15 Şubat15 Mart) araştırmaları ile uyumlu bulunmuştur. Nitekim, Özkarakaş ve ark. (2006) Menemen'de yaptıkları çalışmada 
çiçeklenme dönemlerinin tip ve çeşitlere göre değişim gösterdiği, eriklerin aynı fenolojik evreye gelmelerinde (örneğin ilk çiçeklenme gibi) önemli farkların olmadığ ancak yıllara göre çiçeklenme dönemlerinin farklılıklar gösterdiği bu farkın tomurcuk kabarması ve tomurcuk patlaması dönemlerinde 15 güne kadar ilk çiçeklenme, tam çiçeklenme ve çiçeklenme sonu dönemlerinde bir aya kadar çıktığı raporlanmıştır. Bu bilgiler ışığında yerel erik çeşitlerinin ilk çiçeklenme tarihleri arasındaki bu farklılık genotip özelliklerinden kaynaklanmaktadır.

Yine eriklerin tam çiçeklenme tarihleri de diğer fenolojik özelliklerde olduğu gibi farklılık göstermiştir. Yerek erik çeşitlerinde tam çiçekleme tarihleri 1 Mart-9 Nisan tarihleri arasında gerçekleşmiştir. Bu sonuçların Doğhan (2017)'ın Tokat'taki (8-29 Mart), Yaşar (2019)'ın Iğdır'daki (20-28 Mart) belirlemiş oldukları tarihlerle uyumlu, Hınıslığlu (1997)'nun Erzincan Ovası'ndaki 1995 yılı (2-15 Mayıs) ve 1997 yılı (28 Nisan-11 Mayıs), Beyhan (2005)'in Darende'de ( Nisan ayının son 15 günü içinde), Kuba (2015)'nın Erciş (Van) yöresinde (03-17 Mayıs) belirledikleri tarihlerden daha erken, Özkarakaş ve ark. (2006)'nın Menemen'de (18 Şubat-22 Mart) belirledikleri tarihlerden iklim koşullarına bağlı olarak daha geç olduğu anlaşılmaktadır. Çiçeklenme tarihleri bakımından sonuçların erken ya da geç olmasının başlıca sebebi türdür. Türün içerisindeki çeşitlerde çiçeklenmede farklılıklar görülebilmektedir ki bizim çalışmamızda bu sonucu göstermiştir. Ayrıca çiçeklenme tarihi üzerine iklim olaylarından özellikle sıcaklıkların etkisi önemli bir etkendir. Meyve ağaçları tomurcuklarında görülen dinlenme içsel dinlenme ve takiben zorunlu dinlenme olarak görülmektedir. İçsel dinlenmesini tamamlamış bir tomurcuk sert çekirdekli meyvelerde $+5^{\circ} \mathrm{C}$ nin üzerindeki sıcaklıklarda gelişmeye başlayarak dinlenmeden çıkmaktadır. Araştırmanın yapıldığı bölgede 2016-2017 yıllarında, sıcaklık değerlerine bakıldığında sıcaklıkların bu $\left(+5^{\circ} \mathrm{C}\right)$ değerin üzerinde olduğu görülmektedir. Yine tomurcukların soğuklama istekleri tür ve çeşit bazında farklılıklar göstermektedir. Bu farklılıklar tomurcukların dinlenmeden çıkmasında ve çiçeklenme tarihlerine etki etmektedir. Diğer yandan ekolojik faktörler ve anacın tomurcukların dinlenmeden çıkması üzerine etkili olduğu bilinmektedir. Belirlenen çeşitlerde eriklerin çiçeklenme sonu 10 Mart-20 Nisan tarihleri arasında belirlenmiştir.
Yerel erik çeşitlerin hasat olumu bakımından ilk Can çeşidi 18 Haziran'da, son olarak ise Kara Gügüm ve Güz çeşitleri 31 Ağustos'ta hasata gelmişlerdir. Bu farklılık genotipten kaynakladığı gibi yukarda belirtildiği gibi ekolojik koşullardan da kaynaklanmaktadır. Erikler hasat tarihleri bakımından (18 Haziran-31 Ağustos) önceki çalışmalarla karşılaştırıldığında, belirlenen bu tarihlerin Hınıslıoğlu (1997)'nun Erzincan Ovası'ndaki 1995 yılı (8-17 Ağustos) ve 1997 yılı (6-17 Ağustos), Beyhan (2005)'nın Darende'deki (15 Haziran ile 15 Eylül), Demirsoy ve ark. (2008)'nın Artvin Camili yöresindeki (19 Temmuz-28 Ağustos), Kuba (2015)'nın Erciş (Van) yöresindeki (1 Ağustos-10 Eylül), Doğhan (2017)'in Tokat'taki (13 Haziran- 1 Ağustos), Yaşar (2019)'ın Iğdır'daki (30 Temmuz-10 Ağustos), Moghaddam ve ark. (2011)'nın İran'daki (10 Ağustos -20 Eylül) araştırmalarıyla uyumlu olduğu, Özkarakaş ve Ercan (2003)'nın Menemen'de (erik tiplerinin çoğu mayısın ikinci yarısı ile haziranın ilk haftasında), Özkarakaş ve ark. (2006)'nın Menemen'deki (nisan ayının sonu ile haziran ayının başı) ve Demirsoy (1999)'un Çarşamba Ovası'ndaki (24 Mayıs-16 Haziran) araştırmalarında belirlenen tarihlerden daha geç olduğu görülmektedir. Çalışmada yer alan çeşitlerde tam çiçeklenmeden hasada kadar geçen gün sayısı 110- 179 gün olarak belirlenmiştir. Bu sonuçlar Yaşar (2019)'ın Iğdır'da (148-159 gün) yaptığı araştırma ile örtüştüğü görülmektedir. Moghaddam ve ark. (2011)'nın İran'da yaptıkları çalışmada tam çiçeklenmeden hasada kadar geçen gün sayısı olarak çeşitleri üçe ayrılmışlardır. 110 günden önce hasat edilenler erkenci, 110-150 gün içinde hasat edilenler orta mevsim, 150 günden sonra hasat edilenler geçci olarak belirtilmiştir. Bu sınıflandırmaya göre Giresun ilinde yetiştirilen erik çeşitleri Can çeşidi (110 gün) erkenci, Güz (151 gün), Çıngıl (159), Kara Gügüm (161 gün) ve Kara (179 gün) çeşitleri geçci diğer çeşitler ise orta mevsim olarak gruplandırılabilirler.

Meyve ağırlığı bakımından yapılan değerlendirmede 8.02$169.40 \mathrm{~g}$ olarak belirlenmiş olup, bu değerler ile Hınıslığlu (1997)'nun Erzincan Ovası'nda 1995 yılında (9.7-67.9 g) ve 1997 yllında (9.2-67.2 g), Demirsoy (1999)'un Çarşamba Ovası'nda (15.65 g), Özkarakaş ve Ercan (2003)'nın Menemen'de (9.4-19.5 g), Beyhan (2005)'nın Darende'de (12.63-29.17 g), Miletic ve ark. (2005)'nın Sırbistan'da (4.8-24.3 g), Özkarakaş ve ark. (2006)'nın Menemen'de (9.18-26.35 g), Demirsoy ve ark. (2008)'nın 
Artvin Camili yöresinde (8.90-29.20 g), Bayazıt ve Yılmaz (2011)'ın Mersin'de (13.75-18.54 g), Moghaddam ve ark. (2011)'nın İran'da (16.9-105.8 g), Kuba (2015)'nın Erciş (Van) yöresinde (3.96-25.59 g), Doğhan (2017)'nın Tokat'ta (13.21-52.42 g), Yaşar (2019)'ın Iğdır'da (37.77$80.31 \mathrm{~g}$ ) elde ettikleri araştırma sonuçları ile örtüşmektedir.

Giresun ilinde belirlenen çeşitlerden sadece birinde (İri Can) meyve ağırlığının $169.40 \mathrm{~g}$ olduğu ilde belirlenen diğer çeşitlerin değerlerinden ve daha önce yapılan araştırmalarda bulunan değerlerin çok üzerinde bir değer bulunması bakımından önemlidir. Çalışmamızda meyve eni değerlerinin 20.65-42.06 mm olduğu belirlenmiştir (Çizelge 2) Bu değerler ile Beyhan (2005)'nın Darende'de (25.50-35.00 mm), Miletic ve ark. (2005)'nın Surbistan'da (25.00 mm), Bayazıt ve Yilmaz (2011)'ın Mersin'de (22.02$30.90 \mathrm{~mm}$ ), Kuba (2015)'nın Erciş (Van) yöresinde (17.99$31.22 \mathrm{~mm}$ ), Ansari (2009)'nin İran'da (5.54-19.16 mm) yaptıkları araştırmaları ile örtüşmektedir. Yaşar (2019)'ın Iğdır'da (39.06-50.40 $\mathrm{mm})$ yapılan araştırmasından kısmen daha düşük değerler elde edilmiştir. Bu farklılığın genotipten ve yetiştirme koşullarından kaynaklandığı düşünülebilir. Belirlenen çeşitlerde meyve boyu değerleri 25.42-42.89 $\mathrm{mm}$ arasında belirlenmiştir (Çizelge 2). Bu değerler ile Miletic ve ark. (2005)'nın Sırbistan'da (24.4 mm) araştırmalarından daha yüksek, Beyhan (2005)'nın Darende'de (28.60-43.70 mm), Bayazit ve Yilmaz (2011)'in Mersin'de (24.67-25.69 mm), Kuba (2015)'nın Erciş (Van) yöresinde (18.36-35.86 mm) araştırmalarıyla örtüşmekte ve Yaşar (2019)'ın Iğdır'daki (36.04-65.08 $\mathrm{mm}$ ) araştırmaları ile kısmen daha düşük değerler elde edilmiştir. Çalışmamızda meyve yüksekliği değerlerinin 23.33-43.67 $\mathrm{mm}$ arasında olduğu belirlenmiştir (Çizelge 4.2). Bu değerler, Kuba (2015)'nın Erciş (Van) yöresinde (18.37-33.32 mm) belirlediği değerlerin kısmen üzerinde, Yaşar (2019)'ın Iğdır'daki (25.70-53.19 mm) belirlediği değerlerin kısmen altında, Beyhan (2005)'nın Darende'de (25.30-37.20 mm) belirlediği değerler ile uyumludur. Sap uzunluğu ölçümleri çeşitlerde 11.63-17.64 mm arasında bulunmuştur. Bu değerler, Demirsoy ve ark. (2008)'nın Artvin Camili yöresindeki $(7.40-11.80 \mathrm{~mm})$ araştırmaları ile karşılaştıııldığında çalışmamızda maksimum sap uzunluk değerlerinin kısmen daha yüksek olduğu tespit edilmiştir. Çekirdek ağırlığı değerleri, incelenen çeşitlerde 0.31-1.61 g arasında belirlenmiştir. Bu değerler Özkarakaş ve Ercan (2003)'nın Menemen'de (0.8-1.1 g), Kuba (2015)'nın Erciş (Van) yöresinde (0.38-1.45 g), Yaşar (2019)'ın Iğdır'daki $(0.50-1.33 \mathrm{~g})$ araştırmaları ile örtüşmektedir. Miletic ve ark. (2005)'nın Sırbistan'da (0.3-2.2 g) elde ettikleri sonuçlar ile kısmen örtüşmektedir. Çalışmada belirlenen 20 çeşidin ikisinde (Çıngıl ve Fındık) meyve şekli oval, diğer 18 çeşidin meyve şekli ise yuvarlak olarak tespit edilmiştir (Çizelge 3). Bu sonuçlar, Özkarakaş ve Ercan (2003)'nın Menemen'de (yuvarlak, basık yuvarlak, bir tipin kalp ve bir tipin silindirik), Demirsoy (1999)'un Çarşamba Ovası'nda (küresel), Kuba (2015)'nın Erciş (Van) yöresinde (genotiplerin 19 tanesi eliptik, 26 tanesi yuvarlak) ve Yaşar (2019)'in Iğdır'da (2 genotipte oval, 52 genotipte yuvarlak) yaptıkları araştırma sonuçları ile örtüşmektedir. Çeşitlerde meyve şekli tamamen genotipe özgü bir özelliktir ve bu farklılıkların olması beklenen bir durumdur.

Araştırma yapılan çeşitlerin meyve rengi incelendiğinde 6 çeşidin mor renkte olduğu (Fındık, Kara Buğday, Kara Gügüm, Kemezen, Kara ve Orak), Boğazlı çeşidinin Portakal sarısına yakın sarı renkte, Buğday çeşidinin Portakal sarısına yakın kırmızımsı renkte, Can ve Tombul çeşidinin yeşil renkte olduğu, Civil çeşidinin kırmızımsı mor, Çakal çeşidinin kırmızı, Çıngıl çeşidinin beyazımsı yeşil renkte olduğu, Elma ve Yayla çeşitlerinin menekşe renginde olduğu, Gügüm ve Yumurta çeşitlerinin sarımsı yeşil, Güz çeşidinin yeşilimsi mor, İri Can ve Papaz çeşitlerinin kırmızımsı sarı renkte olduğu belirlenmiştir (Çizelge 4.3). Gözlem sonuçlarının Özkarakaş ve ark. (2006)'nın Menemen'de (açık yeşil, yeşil) ve Kuba (2015)'nın Erciş (Van) yöresinde (15 genotipte 'sarı', 17 genotipte 'kırmızı', 9 genotipte 'açı kırmızı' ve 4 genotipte 'mor' renkli), Yaşar (2019)'ın Iğdır'da (14 genotipte açık mor, 1 genotipte kırmızı, 1 genotipte kırmızı-mor, 27 genotipte mor, 11 genotipte mor-siyah) araştırmaları ile örtüştüğü görülmektedir. Meyve rengi çeşide özgünün yanında özellikle ışıklanma (güneşlenme) süresi, gece-gündüz arasındaki sıcaklık farkı ve rakımdan büyük oranda etkilenmektedir. Bu sebeble bu farklılıkların olması muhtemel bir durum olduğu düşünülmektedir. Yerel erik çeşitlerinde çekirdeğin ete bağlllık durumu incelendiğinde 3 çeşitte çekirdeğin serbest, 3 çeşitte yarı bağlı diğer 14 çeşidin çekirdeğinin ete bağlı olduğu belirlenmiştir (Çizelge 4.3). Bu sonuçlar Kuba (2015)'nın Erciş (Van) yöresinde (11 genotipte 'serbest', 34 genotipte 'bağlı') yapılan araştırma ile örtüşmekte, Yaşar (2019)'ın 
Iğdır'da ( 4 genotip bağlı, 22 genotip serbest, 28 genotip yarı bağlı) yapılan araştırmalarıyla ile kısmen örtüşmekte olduğu görülmektedir. Çekirdeğin meyve etine bağlllık durumu genetik yapı ile ilişkilidir ve o çeşide özgü bir durumdur. Meyve eti/çekirdek oranı değerleri araştırmamızda 17.42175.45 arasında belirlenmiştir. Ayrıca araştırmamızda ikinci en yüksek et/çekirdek oranı 88.05 ve üçüncü en yüksek et/çekirdek oranı 75.48 olarak belirlenmiştir. Bu değerler ile Özkarakaş ve Ercan (2003)'nın Menemen'de (9.44-16.72) araştırmalarına göre daha yüksek değerler belirlenmiş olup Yaşar (2019)'ın Iğdır'daki (27.58-93.93) araştırmalarıyla örtüşmektedir. Araştırmamızda sadece tek bir çeşidin meyve eti/çekirdek oranı 175.45 (İri Can) olup diğer çeşitlere ait değerlerin ve daha önce yapılmış olan çalışmaların çok üzerinde bir değer elde edilmiş olması bakımından önemli bulunmuştur. Meyve tadı açısından çok iyi olarak belirlenen çeşitler: Boğazlı, Buğday, Çıngıl, İri Can, Kara Buğday, Kara Gügüm, Kemezen, Orak ve Yumurta çeşitleridir. Meyve tadı bakımından iyi olarak belirlenen çeşitler: Fındık, Gügüm ve Papaz çeşitleridir. Meyve tadı orta olan çeşitler: Can, Civil, Çakal, Elma, Güz, Kara ve Tombul çeşitleridir. Yayla çeşidinin tadı kötü bulunmuştur. Bu sonuçlar ile Kuba (2015)'nın Erciş (Van) yöresindeki (20 genotipte 'çok iyi', 19 genotipte 'iyi', 4 genotipte 'orta', 2 genotipte 'kötü') Yaşar (2019)'ın Iğdır'da (27 genotip çok tatlı, 21 genotip tatlı, 6 genotip az tatlı) yapmış oldukları çalışmalarla paralellik göstermektedir. Meyvelerin aroması incelendiğinde; Boğazlı, Buğday, Çıngıl, İri Can, Kara Buğday, Kara Gügüm, Kemezen, Orak ve Yumurta çeşitleri zengin aromaya sahip bulunurken Can, Civil, Çakal, Fındık, Gügüm, Güz, Kara, Tombul ve Papaz çeşitleri orta aromalı, Yayla ve Elma çeşitlerinin aroması az olarak belirlenmiştir (Çizelge 4.3). Bu sonuçlar ile Yaşar (2019)'ın Iğdır'da (genotiplerin 20'si orta, 34'ü zengin aromalı) araştırmalarıyla uyumludur. Meyve çeşitlerinde tad ve kendine özgü bir aromasının oluşması genotipe has bir durumdur. Ancak ekolojik faktörler ve yetiştirme koşulları bu özellikleri değiştirebilir. Meyve suyu bakımından çeșitler incelendiğinde 3 çeşidin sulu (İri Can, Orak ve Yumurta) 15 çeşidin orta sulu (Boğazlı, Buğday, Can, Civil, Çakal, Çıngıl, Elma, Fındık, Gügüm, Kara Buğday, Kara, Kara Gügüm, Kemezen, Tombul ve Papaz) 2 çeşidin (Yayla ve Güz) az sulu olduğu belirlenmiştir. Bu sonuçlar ile Kuba (2015)'nın Erciş (Van) yöresindeki araştırmalarıyla (6 genotipte 'az sulu', 8 genotipte 'orta',
31 genotipte 'sulu') uyumlu bulunmuştur. Meyve suyu genotipe özgü olmasının yanında özellikle hava oransal neminin yüksek olduğu yerlere ve sulamanın fazla yapıldığı durumlarda artış görebilmektedir. Suda çözünür kuru madde miktarı araştırmamızdaki çeșitlerde \%7.1218.47 aralığında belirlenmiştir (Çizelge 4.4). Bu değerler ile Hınıslığlu (1997)'nun Erzincan Ovası'nda 1995 y1lı (\%11.6-16.3) ve 1997 yılı (\%10.3-16.2), Demirsoy (1999)'un Çarşamba Ovası'nda \% 7.4, Beyhan (2005)'nın Darende'de (\%9.48-20.66), Miletic ve ark. (2005)'nın Sırbistan'da (\%9.5-14.5), Özkarakaş ve ark. (2006)'nın Menemen'de (\%7.33-13.98) Demirsoy ve ark. (2008)'nın Artvin Camili yöresinde (\%8.50-15.60), Bayazıt ve Yılmaz (2011)'ın Mersin'de (\%9.60-12.60), Kuba (2015)'nın Erciş (Van) yöresinde (\%8.00-19.25), Doğhan (2017)'nın Tokat'ta (\%11.30-18.46), Yaşar (2019)'ın Iğdır'daki (\%11.20-17.70) araştırmaları ile örtüşmektedir. Titre edilebilir asitlik ölçümlerinde çalısmamızda değerler \%1.15-2.83 arasında belirlenmiştir. Bu değerler ile Demirsoy ve ark. (2008)'nın Artvin Camili yöresinde (\%0.10-0.22) belirlediği değerlerin çok üzerinde, Kuba (2015)'nın Erciş (Van) yöresinde (\%0.83-2.81), Demirsoy (1999)'un \%1.05, Yaşar (2019)'ın Iğdır'daki (\%0.711.74) araştırmaları ile benzerlik göstermektedir. Doğhan (2017)'nın Tokat'ta yaptığı çalışmanın bulgularında (7.80-17.13 g/l) çok az değerlere sahip olmuştur. Meyve suyunun $\mathrm{pH}$ değerleri yerel erik çeşitlerinde 2.13-3.83 arasında bir varyasyon göstermiştir (Çizelge 4.4). Bu değerler ile Kuba (2015)'nın Erciş (Van) yöresinde (3.664.40) yapılan araştırmalarla kısmen örtüşmekte, Yaşar (2019)'ın Iğdır'daki (3.01-3.54) araştırmaları ile kısmen uyumludur. Bazı çeşitlerde ise ise daha düşük $\mathrm{pH}$ değerleri kaydedilmiştir. Bu değişim ise çeşide özgü olmanın yanında ekolojik faktörlerden de kaynaklandığı söylenilebilir.

Ağaç habitusu bakımından yörede belirlenen çeşitlerden Civil, Fındık, Kara Gügüm, Kemezen, Orak ve Papaz çeşitlerine ait ağaçların yarı dik, diğer çeşitlere ait ağaçların ise dik yapılı oldukları görülmektedir (Çizelge 4.5). Bu sonuçların Kuba (2015)'nın Erciş (Van) yöresindeki çalışmasıyla (8 genotipte 'dik' 8 genotipte 'yarı dik' ve 29 genotipte ise 'yayvan') kısmen örtüştüğü, Giresun ilinde yetişen erik çeşitleri genellikle ağaçların yarı dik veya dik yapıda oldukları görülmektedir. 
Erik ağaçlarının dallanma durumları bakımından, belirlenen çeşitlerden Çıngıl çeşidinin seyrek dallandığı, Boğazlı, Buğday, Kara Buğday, Kemezen, Orak ve Yumurta çeşidine ait ağaçların orta dallanma gösterdiği diğer 13 çeşitte ağaçların sıkı dallanma gösterdiği görülmüştür (Çizelge 4.5). Çalışmada belirlenen çeşitlere ait ağaçların taç yüksekliği değerleri bakımından en düşük taç yüksekliğinin Çıngıl (3 m) çeşidinde en yüksek taç yüksekliğinin İri Can (14 m) çeşidinde olduğu görülmektedir (Çizelge 4.5). Bu sonuçlar, Beyhan (2005)'nın Darende'de (1.5-5.0 m) ve Kuba (2015)'nın Erciş (Van) yöresindeki (1.50-6.50 m) araştırmalarıyla kısmen benzerlik göstermekle birlikte bazı ağaçlarda bu değerlerin çok üzerinde ağaçların olduğu tespit edilmiştir. Ağacın taç genişliği bakımından çalışmamızda çeşitler arasında en az genişlik Çıngıl çeşidinde $(2 \mathrm{~m})$ en fazla genişlik Orak çeşidinde ( $8 \mathrm{~m}$ ) tespit edilmiştir (Çizelge 5). Bu sonuçlar ile Beyhan (2005)'nın Darande'de (1.004.00 m), Kuba (2015)'nın Erciş (Van) yöresindeki (2.00$7.40 \mathrm{~m}$ ) sonuçlar ile örtüştüğü görülmektedir.Araştırmaya konu olan yerel erik çeşitlerinin ağaçlarında herhangi bir kültürel uygulama yapılmadığından kendi doğal hali ile büyümeye bırakıldıklarından dolayı ağaç özellikleri diğer araştırmalar ile her ne kadar uyumlu olsalar da çeşitler içindeki farklılıkların toprak koşulları ve ağacın yaşı ile ilgili olduğu kanaatindeyiz.

\section{SONUÇ}

Giresun ilinin erik türlerinin gen merkezi içerisinde yer almasından, geniş bir tür ve çeşit zenginliğine sahip olduğu ancak bu zenginliğin giderek kaybolmakta olduğu tespit edilmiştir.. Araştırma yapılan Giresun iline bağlı Merkez, Bulancak ve Keşap İlçelerinde 2016-2017 yıllarında yürütülen bu çalışmada toplam 100 adet erik ağacı incelenmiş olup 20 farklı yerel erik çeşidi (Boğazlı, Buğday, Can, Civil, Çakal, Çıngıl, Elma, Fındık, Gügüm, Güz, İri Can, Kara Buğday, Kara, Kara Gügüm, Kemezen, Orak, Papaz, Tombul, Yayla, Yumurta) tespit edilmiştir.

Doğu Karadeniz Bölgesinde yetiştirilen ürün çeşitliliğinin son 50-60 yılda azaldığı (monokültür tarımın yaygınlaştığı) bilinmektedir (Tanrıvermiş 2006). Bu durum Doğu Karadeniz Bölgesinde yer alan Giresun ili için de geçerlidir. Giresun'da 1.564.264 dekar tarım arazisi varlığının 1.171.903 dekarında (tarım arazilerinin \% 74.91'inde) fındık yetiştirilmektedir (Anonim, 2019). Tarımsal faaliyetlerde risk ve belirsizliklerin olumsuz etkilerinin azaltılması açısından, bölgenin iklim koşullarina uygun ve pazar talebi yüksek olan alternatif ve/veya tamamlayıcı ürün ve faaliyetlerin yaygınlaştırılması önemli bir hale gelmiştir. Bu bakımdan Giresun'da geniş tür ve çeşit zenginliğine sahip yerel erik çeşitlerinin (hızla kaybolmakta olan) alternatif veya tamamlayıcı ürün olarak meyvecilik kültürümüze kazandırılması, yaygınlaştırılması ve Giresun ekonomisine katkı sağlaması gerekmektedir. Araştırmada meyve ağırlığı (169.40 g), et/çekirdek oranı (175.45), meyvelerinin iri olması, erkencilik (Haziran sonu-Temmuz başı), tadının çok iyi ve lezzetli, aromasının zengin ve sulu olması, taze tüketime uygun üstün özelliğe sahip çeşitlerden birisi olan İri Can çeşidinin; Giresun ilinde belirlenen 20 çeşit arasında en yüksek SÇKM değerine sahip (\%18.47) meyve tadı açısından çok iyi, aroma bakımından zengin, sofralık ve kurutmalık tüketime uygun aynı zamanda meyvesi marmelat olarak da tüketilebilen lezzetli bir çeşit olan Kemezen çeşidinin; meyve ağırlığ (75.70 g) bakımından, meyvelerinin iri olması, lezzetli, tadının çok iyi, aromasının zengin, et/çekirdek oranı (88.05) bakımından üstün olması, sofralık ve kurutmalık tüketime uygun olması açısından Kara Buğday çeşidinin; meyve ağırlığı (56.60 g), et/çekirdek oranı (75.48), tadının iyi, orta erkenci bir çeşit (genellikle Temmuz ayında hasat edilmektedir) olması bakımlarından il genelinde yaygınlaştırılması önerilerimiz arasında olması ve kaynak olarak korunmaları ve yaygınlaştırılmaları önerilmektedir. Ayrica yapraklarının kırmızı olması dolayısıyla görünüm itibariyle gösterişli bir çeşit olan Yayla çeşidinin bölgede süs bitkileri yetiştiriciliği açısından park ve bahçelerde kullanılabilir. Araştırmada belirlenen çeşitler içerisinde ülkemizde yetiştirilen çeşitler bulunmasına rağmen bazı çeşitler Giresun yöresine özgüdür. Bu çeşitlerin ülkemiz gen kaynaklarına kazandırılması gerekmektedir. Ayrıca bu çeşitler bölgede hiçbir kültürel uygulama yapılmadan yetişitirilmektedir ağaçlar sağlıklı görünümdedir. Bu yönü ile belirlenen çeşitler özellikle hastalık ve zararlılara karşı dayanım yönünde değerli bitkisel materyallerdir.

\section{AÇIKLAMA}

Çalışmanın yürütülmesi ve sonuçların yazılması esnasında araştırma ve yayın etiğine uyulmuştur.

Herhangi bir "Çıkar Çatışması" bulunmamaktadır. Makalede yazarlar eşit oranda katkı sağlamıştır. 
Çalışma Canan ÖNCÜL'ün Yüksek Lisans Tezinden üretilmiştir.

\section{KAYNAKLAR}

Anonim, 2019. 2019 yılı altı aylık faaliyet raporu, Giresun İl Tarım ve Orman Müdürlüğü Kayıtları, Giresun.

Anonim, 2020a. The State of Food and Agriculture 2019. FAO, Rome. http://www.fao.org-(Erişim Tarihi: 13.11.2020).

Anonim, 2020b. Türkiye İstatistik Kurumu (TUİK). (www. tuik.gov.tr)-(Erişim tarihi: 13.11.2020).

Ansari, R., Sedaghathoor, S., Allahyari, M. S., Nasiri, E. 2009. Comparison of morphological characteristics of some plum and prune cultivars of Iran. Scientific Research and Essay, 4 (10), 992-996.

Ayanoğlu, H. 1995. Doğu Akdeniz Bölgesi'nde sofralık erik. Yüksek Lisans Tezi, Çukurova Üniversitesi, Fen Bilimleri Enstitüsü, Bahçe Bitkileri Anabilim Dalı, Adana.

Balık, S. 2005. Kahramanmaraş'ta dış satıma yönelik Japon Grubu (Prunus salicina Lindl.) sofralık yeni erik çeşitlerinin yetiştiriciliği üzerine araştırmalar. Yüksek Lisans Tezi, Sütçü İmam Üniversitesi Fen Bilimleri Enstitüsü, Kahramanmaraş.

Bayazıt, S., Yılmaz, S. 2011. Bazı can erik (P. cerasifera Ehrh.) çeşit ve seleksiyon tiplerinin Mut (Mersin) ekolojisindeki meyve özellikleri. Mustafa Kemal Üniversitesi, Ziraat Fakültesi Dergisi, 16(1), 1-9.

Beyhan, Ö. 2005. Darende'de yetiştirilen bazı standart ve mahalli erik çeşitlerinin pomolojik, fenolojik ve morfolojik özelliklerinin belirlenmesi üzerine bir araştırma. Bahçe, 34(2), 47-56.

Çalışkan, O., Polat, A. A. 2011. Yeşil olum ve tam olum dönemlerinde derilen bazı can erik (Prunus cerasifera L.) genotiplerinin meyve kalite özelliklerindeki değişimler. Türkiye VI. Ulusal Bahçe Bitkileri Kongresi, 4-8 Ekim 2011, 817-822.

Çelikkol, B.P. 2011. Önemli erik (Prunus sp.) gen kaynaklarının SSRs (Simple Sequence Repeats)'a dayalı genetic karakterizasyonu. Yüksek Lisans Tezi, Ankara Üniversitesi, Fen Bilimleri Enstitüsü, Biyoloji Anabilim Dalı, Ankara.

Demirsoy, H. 1999. Çarşamba Ovası̀nda can erik tiplerinin (P. cerasifera Ehrh.) tiplerinin seleksiyon yoluyla islahı ve selekte edilen bazı tiplerin şeftali ve erikler için klon anaç olarak kullanılabilirliklerinin saptanması üzerine araştırmalar. Yüksek Lisans Tezi, Ondokuz Mayıs Üniversitesi, Fen Bilimleri Enstitüsü, Bahçe Bitkileri Anabilim Dalı, Samsun.

Demirsoy, H., Balcı G., Öztürk, A., Serdar, Ü. 2008. Saklı cennet Camili'de yetiştirilen yerel erik ve kiraz çeşitleri. Türkiye V. Ulusal Bahçe Bitkileri Kongresi, 04-07 Eylül 2007, Erzurum. 357-360

Doğhan, Ş. 2017. Tokat ilinde yetiştirilen bazı yerel erik (Prunus sp.) çeşitlerinin fenolojik ve pomolojik özelliklerinin belirlenmesi. Yüksek Lisans Tezi, Gazi Osman Paşa Üniversitesi, Fen Bilimleri Enstitüsü, Bahçe Bitkileri Anabilim Dalı, Tokat.

Gavi, R., Anderlini, R. 1978. Plums. Nature, 104-113 Edizoni Annuari d'Italia. Bologna-Italy.

Hıdır, A., Koser, A., Dervişoğlu, E., Tekbaş, T., Dada, A.S., Akbay, Z., Ayaz, A., Özdemir, M., Çetinkaya, G. 2005. Giresun İl Çevre Durum Raporu. Giresun Valiliği İl Çevre ve Orman Müdürlüğü, Giresun.

Hınıslığlu, E. 1997. Erzincan Ovası'ndaki yetiştirilen bazı erik çeşitleri üzerinde fenolojik, biyolojik ve pomolojik araştırmalar. Yüksek Lisans Tezi 84s,, Atatürk Üniversitesi, Fen Bilimleri Enstitüsü, Bahçe Bitkileri Anabilim Dalı, Erzurum.

Kuba, G. 2015. Erciş (Van) yöresinde doğal olarak yetişen eriklerin (Prunus domestica L.) seleksiyonu. Yüksek Lisans Tezi, Yüzüncü Yll Üniversitesi, Fen Bilimleri Enstitüsü, Bahçe Bitkileri Anabilim Dalı, Van.

Mendilcioğlu, K. 1980. Bazı can eriklerinin odunsu çeliklerle çoğaltılması üzerine araştırmalar. Ege Üniversitesi, Ziraat Fakültesi Dergisi, 17(3), 85-98. Miletic, R., Zikic, N., Nikolic R. 2005. Pomological And Technological Characteristıcs Of Collected Selections Of Cherry Plum (Prunus cerasıfera E.). Genetica, 40, 39-47.

Moghaddam, G., Hossein, S., Akhavanc, S., Hosseinid, S. 2011. Phenological and pomological characteristics of some plum (Prunus spp.) cultivars grown in Mashhad, Iran. Crop Breeding Journal, 1(2), 105108.

Müftüoğlu, O. 2004. Yaşasın Hayat. ISBN-975-293-0670, İstanbul, 336s.

Özbek, S. 1978. Özel Meyvecilik. Çukurova Üniversitesi, Ziraat Fakültesi Yayınları, No:128, Adana. 
Özçağıran, R., Ünal, A., Özeker, E., İsfendiyaroğlu, M. 2003. Ilıman İklim Meyve Türleri, Sert Çekirdekli Meyveler, Cilt I, E. Ü. Zir. Fak., 553, 229s.

Özkarakaş, İ., Ercan, N. 2003. Güneydoğu Anadolu ve Karadeniz Bölgeleri'nden toplanan bazı erik ( $P$. Cerasifera Ehrh.) genetik kaynakları materyalinin değerlendirilmesi. Anadolu Journal of AARI, 13(1), 91-106.

Özkarakaş, İ., Ercan, N., Gürnil, K. 2006. Ege Bölgesi’nden toplanan bazı yeşil erik (P. Cerasifera Ehrh.) materyalinin değerlendirilmesi. Anadolu Journal of AARI, 16(2), 35-49.

Özvardar, S., Önal, M.K. 1990. Erik yetiştiriciliği. Tarımsal Araştırmaları Destekleme ve Geliştirme Vakfi, yayın no: 23, Yalova.

Subaşı, E. 2013. Isparta ekolojik koşullarında bazı erik çeşitlerinin gelişme, verim ve meyve kalite özelliklerinin belirlenmesi. Yüksek Lisans Tezi, Süleyman Demirel Üniversitesi, Fen Bilimleri Enstitüsü, Bahçe Bitkileri Bölümü, Isparta.

Tanrıverdi, H. 2006. Doğu Karadeniz Bölgesi'nde fındık çay ve kivi tarımının ekonomik analizi ve monokültürün etkilerini azaltabilme olanakları. Ankara Üniversitesi Basımevi, Ankara.

Tunalığlu, R., Keskin, G. 2004. G. T. E. A. E. Bakış. Tarımsal ekonomi araştırma enstitüsü, 7, 9.

Yaşar, Ö. 2019. Iğdır'da yetişen yerli karaerik (Prunus domestica L.) genotiplerinin fenolojik, pomolojik ve morfolojik özelliklerinin belirlenmesi. Yüksek Lisans Tezi, Iğdır Üniversitesi, Fen Bilimleri Enstitüsü, Bahçe Bitkileri Anabilim Dalı, Iğdır. 